J O U R N A O F French and Francophone Philosophy
REV UE DE LA

philosophie française et de langue française

\title{
Letter to Néméla
}

\section{Albert Memmi}

Journal of French and Francophone Philosophy - Revue de la philosophie française et de langue française, Vol XIX, No 2 (2011) pp 9-10

\author{
Vol XIX, No 2 (2011) \\ ISSN 1936-6280 (print) \\ ISSN 2155-1162 (online) \\ DOI $10.5195 /$ jffp. 2011.506 \\ www.jffp.org
}

\section{(cc) EY-NC-ND}

This work is licensed under a Creative Commons Attribution-Noncommercial-No Derivative Works 3.0 United States License.

\section{ULIS D-Sunt}

This journal is operated by the University Library System of the University of Pittsburgh as part of its D-Scribe Digital Publishing Program, and is co-sponsored by the University of Pittsburgh Press 


\section{Letter to Néméla}

\section{Albert Memmi}

Paris, May 26, 2011

My dear Néméla,

A funny quid pro quo has occurred. I said to myself that what I wanted to tell you in this letter could be used for this unexpected address. Then they warned me that I would only have a few minutes. So here I am returning to what I wanted to tell you and that I did not get to say the other night. Too bad for the organizers and the audience.

In fact, by your poem-letter, you have shown me that you have seen perfectly the matrix and the essence of my work: it is the feeling, strongly experienced and deeply-rooted, that there are injustices are almost everywhere, that people suffer from them, and that one must, I must, fight them. This is also the meaning, either implicit or explicit, of the social contract. This is why humans join together: in order for each to do well in association. Unfortunately (such is the human being), there are skilled people who want to have more, even to the detriment of other members as well as to groups themselves, who become cancerous in some way, and who defraud and crush individuals.

For me, this leads to a philosophy, an ethics and a method.

Philosophy, what I mean by philosophy, is the struggle to capture and regain solidarity. But this solidarity is without accommodation or compromise, and it would be falsified by either one. And one does not serve the destitute (and what is their own) by not telling them the exact truth.

So, first of all, always seek the truth and then try to communicate it. These two steps do not always go hand in hand. One can be unable to communicate the truth, sometimes because there is danger in doing so. Descartes and Spinoza decided to keep their assets in a drawer. Others were tortured or imprisoned for having the audacity to show the truth. 
But, all things considered, that is the "mission" of the thinker. To do this, one must always follow the teachings of reason: mistrust prejudices (those of one's own group as well!) and utopias. Utopias are a form of collective lie (religions, ideologies, tactics).

Only in this way can one arrive at a true humanism, which is simply to say that the human being is what is most important, not groups, interests, illusions of any kind, or supposedly sensible causes. The sacred is whatever we claim to be such; it has no basis.

In passing: is there no room for fiction? Have I myself not written and published stories and even poems? But fiction allows us to express and to suggest what cannot be rendered through concepts: occasional emotions or the sense of the unknown. How can concepts express the turmoil that femininity arouses (or masculinity for women, I suppose) or the tenderness that is felt toward a child? We use the arts and poetry for this. In short, have recourse to fiction but know and always remember that they are fictions and that reason must decide in the end, on the basis of reflective and collectively controlled experimentation.

Therefore, always start from the real and conceptualize afterwards. It then becomes possible to propose some tools. This is what I have sought to do with the concept of judéité, which was fortunate enough to be adopted by the dictionary, hétéropathie, and the notion of the duo (which was the basis for my work on dependency and later on dominance).

To bring this long letter to an end, lets come to my political "commitments": they are never based on accommodations or equivocations. This rigor is not always understood, as in the case of the secular. Too bad, I would have found my career.

I must confess that this also brings me some "contentment"; it is for this reason that I have written three short works on the possibility of happiness. I have neither disdain nor avidity for goods, but a tendency to find serenity, if at all possible, in the "small joys."

Forgive me for being long, but I have tried to make my answers to your questions coherent. And you have guessed them! They are also found in your poem-letter.

And, what is more, as I said in my previous letter, it is your approval that gave me strength.

So thank you.

Affectionately, 